\title{
UNIWERSALIZM TOMIZMU I JEGO AKTUALNOŚĆ W ŚWIETLE PERSONALIZMU JACQUES'A MARITAINA
}

Analizując kontekst historyczny i atmosferę światopoglądową, w której kształtuje się personalizm Jacques'a Maritaina, możemy wręcz stwierdzić, iż z góry jest on skazany na zapomnienie, a co najmniej na ostrą krytykę. Środowisko rodzinne antyklerykalne, scjentyzm królujący na Sorbonie, kryzys w samym Kościele stanowią atmosferę nieufności wobec metafizyki i jakiegokolwiek odwołania do wymiaru nadprzyrodzonego. Niemniej jednak Maritain nie ustaje w poszukiwaniu prawdy, która byłaby źródłem nadziei i nadałaby właściwy sens zarówno w jego życiu, jak i w życiu jego żony Raïssy. Wykłady Bergsona, na które uczęszcza, orientują jego badanie w kierunku metafizyki, jako jedynej przestrzeni, w której człowiek poznaje rzeczywistość poprzez intuicję intelektualną. Niemniej jednak na drodze jego poszukiwań trzeba wymienić przede wszystkim Leona Bloy, a potem dominikanina Humberta Clérissaca, którzy zapewniają Maritaina, że prawda jest osiągalna poprzez możliwości naturalne człowieka. Ostatecznie za namową Humberta Clérissaca Maritain czyta dzieła Akwinaty ${ }^{1}$. Owa głębia prawdy u Maritaina znajduje zatem najlepszy wyraz w doktrynie św. Tomasza z Akwinu. Dlatego skoncentrujemy się na owej analizie filozofa francuskiego, aby przedstawić wymiary uniwersalne myśli scholastycznej, które pozwalają zrozumieć rzeczywistość w jej obiektywności. W związku z powyższym najpierw musimy zrozumieć pytanie: dlaczego Maritain oparł swoją wizję człowieka na geniuszu św. Tomasza z Akwinu? Co spowodowało, że francuski filozof odwołuje się do myśli scholastycznej? W niniejszym artykule będziemy czerpać z dorobku Maritaina, który został zgrupowany i tworzy zbiór siedemnastu tomów. Zostały one wydane przez wydawnictwo uniwersytetu we Fryburgu, w Szwajcarii w latach

Por. S. Kowalczyk, Jacques Maritain (1882-1973). Tomista otwarty na wspótczesność, w: Jacques Maritain prekursor soborowego humanizmu, red. E. Balawajder, S. Kowalczyk, Wyd. KUL, Lublin, 1992, s. 9-24. 
1986-2007 (CEuvres Complètes de Jacques et Raïssa Maritain, les Éditions Universitaires Fribourg, Suisse).

Najważniejszym aspektem antropologii Maritaina jest realizm zaproponowany przez św. Tomasza z Akwinu w jego doktrynie. Dzięki Akwinacie, Maritain odkrywa filozofię nie jako ideologiczny dyskurs, ale jako sposób, aby w pełni zrozumieć rzeczywistość świata, a szczególnie istoty ludzkiej. Według Stanisława Fumeta takie ujęcie świata pozwala wykluczyć wizję człowieka, którą prezentują idealizm i irracjonalizm, a która w swej głębi jest antyludzka².

\section{SPECYFIKA WIZJI CZEOWIEKA U JACQUESA MARITAINA I JEGO RELACJA WOBEC MODERNIZMU}

Dla Maritaina modernizm pozbawiony jest realizmu. Humanistyczny renesans, reformacja protestancka i racjonalistyczne Aufklärung to trzy antropologiczne kryzysy,w których człowiek dokonał historycznej rewolucji o niezrównanym znaczeniu. Uznał siebie za centrum swojej historii i ostateczny koniec swojego działania na ziemi i przypisał sobie prawdziwie boski przywilej absolutnej niezależności ${ }^{3}$. Człowiek, popadłszy w iluzję wszechmocy, jest podzielony i rozłączony. W wyniku tego dochodzi do najpoważniejszego rozłamu, który możemy określić jako separację między człowiekiem a prawdą o nim samym. Maritain przedstawia tę sytuację jako rodzaj egzystencjalnej katastrofy człowieka. W obliczu tej antropologicznej zmiany Maritain wskazuje na jedno rozwiązanie: powrót do zrozumienia człowieka w jego uniwersalnych wymiarach. Człowiek nie znajduje pełnej jedności w sobie. Musi jej szukać poza sobą. Człowiek, myśląc, że jest całkowicie niezależny, zagubił się. Odnajdzie się jedynie wtedy, kiedy oprze swoje życie na zasadach, które go przekraczają. Obiektywizm zatem jest pierwszym warunkiem jedności ${ }^{4}$. Powyższe rozważania ujawniają fundamentalne rozróżnienie dokonane przez Maritaina między antropocentrycznym i teocentrycznym humanizmem, oczywiście na korzyść tego drugiego. W tym kontekście wizja św. Tomasza z Akwinu otwiera szeroką perspektywę zarówno na dialog ze współczesnym światem, jak i na „ożywienie metafizyki”. Ta synteza, którą przedstawia Maritain, stanowi podstawę jego nauczania i jego działania. Zatem filozof pozostaje cały czas wierny św. Tomaszowi, usiłuje jednocześnie zaaplikować jego myśl w kontekście współczesnego świata.

Studia nad tomizmem nie oznaczają, że Maritain wycofuje się z debaty o wpływach modernizmu na człowieka. Wręcz przeciwnie, angażuje się, aby przedstawić

2 Por. S. Fumet, Amour de la sagesse et amitié des hommes, „Recherches et débats du centre catholique des intellectuelles français", (1957)19, s. 23-33.

3 Por. J. Maritain, Le Docteur Angélique, Euvres Complètes, 1983, t. 4, s. 65.

4 Por. tamże, s. 66. 
spójną i racjonalną myśl. Doktryna tomistyczna, wyjaśnia Maritain, przez swą uniwersalność przekracza epokę średniowiecza. Jest nieskończenie aktualna w każdej epoce, ponieważ odpowiada na wezwania obecnego czasu ${ }^{5}$. Tak więc, dla Maritaina antymodernizm nie oznacza zaniedbania współczesnego świata, ale kontakt z daną rzeczywistością przy zachowaniu własnej filozoficznej sylwetki. W tej perspektywie filozof jest antymodernistą, wykazując błędy modernizmu i jednocześnie ultranowoczesny, poprzez dialog i wizję nowatorską humanizmu integralnego. Maritain utrzymuje obraz świata, w którym człowiek może odczytać sens swojej egzystencji. Niemniej jednak to, co prezentuje Maritain, zawiera bardzo innowacyjny projekt. Mianowicie, chce on przedstawić wizję człowieka, zarówno w jego działaniu, jak i w jego istnieniu, nie tracąc z pola widzenia wysoce spekulatywnego i intelektualnego myślenia. Dlatego odwołuje się do filozofii chrześcijańskiej, której doktrynalna głębia pozwala stawić czoło ateistycznemu humanizmowi i znaleźć praktyczną prawdę w porządku doczesnym, aby odnowić struktury społeczne ${ }^{6}$. W tym rozległym temacie Maritain rozumie chrześcijański ideał (l'idéal historique chrétien), zrealizowany w czasie. Dlatego, kiedy mówi sam o sobie „ultramodernista”, zakłada odnowienie poprzez wysiłek naukowy i w ciągłości z dorobkiem tradycji.

Modernizm eksponuje wizję człowieka jednostronnie, jako autonomiczną jednostkę, bez koniecznej relacji z Bogiem, gdzie normy transcendentalne też nie stanowią podstawowego elementu wizji świata i działania człowieka. Taka sytuacja dla Maritaina jest formą rozpadu ontologicznego ${ }^{7}$, co prowadzi go do wewnętrznej pustki, ponieważ z jednej strony mówi, że jest autonomiczny, a z drugiej strony człowiek czuje się coraz bardziej uzależniony od swoich pragnień. Niemniej jednak zauważalny rozpad porządku świata nie oznacza dla Maritaina końca czasu. Wręcz przeciwnie, Maritain stale utrzymuje wizję nowego humanizmu, który przygotowywany jest w obecnej agonii świata, a jednocześnie przygotowuje odnowę cywilizacji ${ }^{8}$. To, co proponuje Maritain, to nie zniszczenie świata, ale raczej jego przemiana przez zaangażowanie nie tylko na płaszczyźnie filozofii, ale i w wymiarze społecznym. Ponieważ, jak podkreśla, nie ma błędu, który nie zakłada pewnej prawdy9. I w obliczu fałszywej doktryny, filozof jest w stanie uchwycić cząstkową prawdę, a tym samym ująć rzeczywistość samą w sobie.

Por. tenże, Antimoderne, Euvres Complètes, 1987, t. 2, s. 929.

6 Por. tenże, Lettre sur l'indépendance, Desclée de Brouwer, Paris 1935, s. 22.

7 Por. tenże, Le Paysan de la Garonne, Desclée De Brouwer, Paris 1966, s. 162.

8 Por. tenże, Le crépuscule de la civilisation, Euvres Complètes, 1988, t. 7, s. 12.

9 Por. tenże, Antimoderne, dz. cyt., s. 1039. 


\section{a. deprecjacja inteligencji}

Najbardziej tragicznym skutkiem współczesnych czasów dla Maritaina jest marginalizacja inteligencji, która swoimi korzeniami sięga czasów renesansu. Rozum zbacza z drogi rozumowania obiektywnego wtedy, gdy rezygnuje z intelektualnej intuicji. W końcu neguje cały dorobek tradycji intelektualnej i filozofii klasycznej, a przede wszystkim metafizykę. Jeśli mówimy o kryzysie, musimy zatem dostrzec jego źródło, które tkwi w rozumieniu inteligencji, źle uporządkowanej i pozbawionej właściwego jej powołania. Tak więc, zamiast odkrywać prawdę, przedstawia ona abstrakcyjne, a nawet irracjonalne rozwiązania, które nie znajdują spójnego miejsca w ludzkim działaniu. Ta sytuacja jest porównywana przez Maritaina do spektaklu, którego jesteśmy świadkami, a w którym irracjonalizm zniekształca misję inteligencji. Ostatecznie jesteśmy świadkami tragicznej opozycji między życiem a inteligencją ${ }^{10}$. Widzimy więc, dlaczego Maritain zawsze utrzymuje ścisły związek między prawdą a rozumem. Związek ten jest koniecznym warunkiem rozumowania, który nie może być błędny, ponieważ ma na celu zrozumienie źródła każdego ludzkiego wymiaru: duchowego, relacyjnego, osobistego, społecznego lub politycznego. Niemniej jednak Maritain twierdzi, iż rozum jest w stanie spostrzec to, co jest nieracjonalne i zniekształca rzeczywisty obraz rzeczywistości ${ }^{11}$. W rezultacie przymiotnik ,,irracjonalny” używany jest przez modernizm jako niedający się sprowadzić do logicznego rozumowania i niezgodny $\mathrm{z}$ danymi rozumu. Taka wizja poznania ogranicza rolę inteligencji i ostatecznie zniekształca jej działanie w aspekcie duchowym. W ten sposób intelekt staje się coraz bardziej bezsilny, aby poradzić sobie z pytaniami metafizycznymi, takimi jak: przyczyny pierwsze lub najwyższe zasady. W końcu, poprzez degradację inteligencji dochodzimy do kolejnego wynaturzenia: rozum usiłuje ustanowić siebie jako najwyższą miarę prawdy, co ostatecznie prowadzi do redukcji wszystkich rzeczy do pojęć, które odnajdujemy w sobie poprzez minimum eksperymentalnego kontaktu z rzeczywistością (pojęć, które są sprowadzalne do danych matematyki i geometrii) ${ }^{12}$.

Studia nad tomizmem, w szczególności odkrycie filozofii w jej spekulatywnym i uniwersalnym wymiarze, wynika u Maritaina z krytycznego spojrzenia na sceptycyzm i pesymizm wiedzy w epoce modernizmu. Wszystko to, co modernizm uważa jako sukces intelektualny (naturalizm, indywidualizm, degradacja metafizyki) dla filozofa, jest zaburzeniem myśli scholastycznej. Niemniej jednak według Maritaina degeneracja wyższego systemu prowadzi do innego systemu, gorszego od tego pierwszego. W tym kontekście Maritain mówi: „Corruptio unius genera-

10 Por. tenże, Le crépuscule de la civilisation, dz. cyt., s. 15.

11 Por. B. Krol, Osobowość, wolność i rozumność człowieka w świetle wybranych dzieł Jacques'a Maritaina, „Studia Teologiczno-Historyczne Śląska Opolskiego”, (2014)34, s. 53-66.

12 Por. J. Maritain, La Philosophie bergsonienne, Euvres Complètes, 1986, t. 1, s. 190. 
tio alterius"13. Tak więc marginalizacja scholastyki powoduje rozkwit innych myśli: indywidualizmu, modernizmu. Taka sytuacja powoduje, że Maritain opracowuje teorię poznania w oparciu o tomizm, aby w pełni uchwycić rzeczywistość we wszystkich jej wymiarach, a nie tylko przez zewnętrzne zjawiska, uchwytne poprzez zmysły ${ }^{14}$. Według Maritaina nauki ścisłe opierają się na metafizyce mechanistycznej. Pomijają one wysiłek inteligencji w poszukiwaniu prawdziwych przyczyn, opierając się na matematycznych funkcjach i zmianach ilościowych możliwych do zaobserwowania w naturze. Tak więc waloryzacja współczesnych nauk i zaniedbanie innych rodzajów wiedzy powoduje deprecjację filozofii. Nawet Bergson, którego filozofia otworzyła Maritaina na Absolut, nie zadowala go. Bergsonowska wizja intelektu, niezdolnego do osiągnięcia istoty rzeczy, jest nie do zaakceptowania i powoduje, że Maritain skłania się ku ujęciu intuicyjnemu bytu, które pozwala nie tylko odkryć istotę, ale również zrozumieć prawdę o danej rzeczy.

Zagrożeniem najpoważniejszym, które zniekształca obraz człowieka jest niedobór, a nawet zniknięcie metafizycznych inspiracji w przestrzeni społecznej i naukowej. Pozytywizm i scjentyzm wyznaczyły inną metodę badań, ograniczając zakres badań do danych określonych przez nauki ścisłe. Pozytywistyczna atmosfera spowodowała dysharmonię między intelektem i teorią poznania: człowiek nie odnosi się już do transcendentalnych zasad, ale do postępu technicznego, który stał się jego najwyższym dobrem. W obu wymiarach (teoria wiedzy i bytu) Maritain dostrzega wielki niedostatek i zwraca się ku tomizmowi, aby je pogłębić i skonstruować koncepcję człowieka dobrze zakotwiczonego w świecie. Realizm egzystencjalny Akwinaty umożliwił mu skonstruowanie własnej wizji człowieka, gdzie akcentuje się egzystencję, jako ten wymiar, który implikuje i ratuje esencję ${ }^{15}$.

Deprecjacja metafizyki znajduje odzwierciedlenie nie tylko w spojrzeniu na świat, ale także w sposobie ujęcia wartości moralnych. Przeciwstawiając się konformizmowi etycznemu, Maritain zwraca się do intelektualistycznego charakteru moralnego postępowania. Wadą inteligencji w dobie modernizmu jest to, że modernizm odrzuca nadprzyrodzony porządek, uznając go za nieosiągalny, a nawet niemożliwy. W ten sposób akcentuje się naturalizm, który zaprzecza nie tylko wymiarowi łaski, ale także ontologicznemu aspektowi ludzkiego działania. Relacja do sacrum jest całkowicie kwestionowana i Bóg nie jest już tym, który formułuje zasady społeczne lub moralne. Państwo jest postrzegane przez kategorie laickości, które podkreślają siłę rozumu i wolę obywateli. Dla Maritaina zanegowanie Boga ma swoje bardzo konkretne konsekwencje: współczesny świat odwró-

\footnotetext{
13 Tenże, Antimoderne, dz. cyt., s. 1025.

14 Por. tamże, s. 1031.

15 Por. tenże, Court traité de l'existence et de l'existent, Euvres Complètes, 1990, t. 9, s. 15.
} 
cił porządek i uczynił akt czysty zależny od nas. $\mathrm{Z}$ tego wynika jeden wniosek: rozpacz ${ }^{16}$.

Kontynuując swoje rozważania, filozof analizuje kolejną formę degeneracji inteligencji: wizja człowieka jako czystego i doskonałego ducha. Stwarza to obraz w pełni autonomicznego, samowystarczalnego i dominującego człowieka nad naturą. Takie podejście Maritain nazywa antropocentrycznym indywidualizmem lub angelizmem, co zdecydowanie powoduje uwięzienie człowieka w samym sobie. Cywilizacja w obecnym stanie, znajdująca się w głębokim kryzysie, musi zostać odnowiona przez światło metafizyki. W tym kontekście geniusz Akwinaty wznosi się ponad agnostycyzm i racjonalizm, a także przywraca w ludzkim umyśle właściwą hierarchię spekulatywnych wartości, rozpoczyna w nas porządek mądrości ${ }^{17}$. W ten sposób możemy nie tylko potwierdzić powszechność prawdy, ale także wykazać błędy modernizmu, aby oczyścić wszystkie przestrzenie, w których człowiek rozkwita: społeczeństwo, kultura, religia, sztuka itd. Tak więc myśl św. Tomasza jest dla Maritaina doktryną, która pozostaje zawsze obecna i owocna, i aktualna. Innymi słowy, projekt opracowany przez św. Tomasza z Akwinu, według Maritaina, ma ambicję być uniwersalną prawdą. Dlatego tomizm jest filozoficzną podstawą Maritaina w całej jego pracy intelektualnej i społecznej. Uniwersalizm tomizmu ma szerokie znaczenie u Maritaina. System tomistyczny jest uniwersalny nie tylko przez afirmowane prawdy, które wykraczają poza czas, a nawet poza społeczeństwo, ale także przez jego przeznaczenie. Innymi słowy, to nie tylko teologowie powinni zgłębiać naukę św. Tomasza. Maritaina przedstawia nam tomizm nie jako doktrynę seminariów, ale jako system naturalny ludzkiego umysłu, co stanowi o jego uniwersalnym wymiarze ${ }^{18}$.

\section{b. Zniekształcony obraz rzeczywistości}

Katastrofa modernizmu znajduje swoje wyjaśnienie w ,angelizmie” Kartezjusza. Maritain wyjaśnia swój pogląd w ten sposób - powiedzieć wszystko w trzech słowach: niezależność wobec rzeczy. Taką właśnie postawę obrał Kartezjusz, kiedy waloryzuje myśl ludzką ${ }^{19}$. Ta idea autonomii stoi w sprzeczności z klasyczną wizją rzeczywistości jako „adaequatio rei et intellectus”. Kartezjański dualizm otworzył perspektywę postrzegania człowieka jako istoty biologicznej, dobrze zmechanizowanej. Oczywiście jest to delikatne i kruche stworzenie, ale mimo wszystko pozostaje „maszyną”. Dlatego krytyka Maritaina koncentruje się na wizji cielesnego wymiaru egzystencji jako jedynie „res extensa”, ponieważ taka koncepcja

16 Por. J. Cocteau, J. Maritain, Correspondance 1923-1963, red. M. Bressolette, P. Glaudes, Éditions Gallimard, Paris 1993, s. 340.

17 Por. J. Maritain, Le Docteur Angélique, dz. cyt., s. 70.

18 Por. tenże, Antimoderne, dz. cyt., s. 1035.

19 Por. tenże, Trois réformateurs, Euvres Complètes, 1984, t. 3, s. 487. 
deprecjonuje wymiar duchowy i nadprzyrodzony. W ten sposób humanizm, od czasów renesansu, przedstawia zniekształconą koncepcję człowieka i kultury. Popiera ideę natury ludzkiej absolutnie autonomicznej ${ }^{20}$. To zatem ten obraz natury zamkniętej w sobie jest błędny i nie pozwala człowiekowi stać się bardziej człowiekiem. Wreszcie antropocentryczne spojrzenie ujmuje świat ze szkodą dla samego człowieka, pozbawiając go wszystkich jego wymiarów nadprzyrodzonych. Trzeba nam jeszcze podkreślić, iż irracjonalny dramat wynika $\mathrm{z}$ racjonalnego humanizmu. Innymi słowy, rozum jest zagrożony przez gloryfikowanie rozumu, co powoduje, że człowiek nie może wejść w świat duchowy. Rzeczywistość została zatem odczytana kosztem intelektu i z pogardą dla prawdy. I właśnie to odkrycie pomaga nam zrozumieć zarówno stosunek Maritaina do modernizmu, jak i otwartość na tomizm. Niemniej najbardziej niebezpieczne jest to, że modernizm nawet nie wysila się, aby przeanalizować tezy filozofii klasycznej ${ }^{21}$. W rezultacie przeciętność modernizmu spowodowała degradację inteligencji, a w konsekwencji deprecjację metafizyki. Powyższa analiza doprowadza naszego filozofa do jedynej konkluzji: trzeba powrócić do filozofii, która zarówno opiera się na pierwszych przyczynach, a także pozostaje zawsze posłuszna rzeczywistości. Taka filozofia ma swe podstawy w myśli Arystotelesa i św. Tomasza ${ }^{22}$. Dzięki nim Maritain odkrywa zdolności poznawcze intuicji intelektualnej, która jest drogą do zrozumienia rzeczywistości.

\section{WYMIAR UNIWERSALNY TOMIZMU}

We wrześniu 1910 roku Maritain zaczyna czytać Sumę Teologiczna św. Tomasza z Akwinu, w której to „intelekt znajduje swoją ojczyznę"23. W zasadzie to Raissa zaczyna czytać dzieło św. Tomasza, a Jacques Maritain podąża za przykładem swojej żony dopiero po roku.

Atmosfera, w której Maritain zaczyna zgłębiać tomizm, nie była przychylna. Kościół również pogrążył się w kryzysie modernistycznym. Sytuację taką wywołuje nieufność Kościoła nie tylko w odniesieniu do danych naukowych, ale także w odniesieniu do tradycji, która nie uznaje żadnego filozoficznego wyjaśnienia tomizmu. W tej sytuacji myśl antropologiczna Maritaina może wywoływać podejrzenia o wypaczenie nauczania scholastycznego. W rezultacie Maritain musi być ostrożny w swoich badaniach. Ponadto przedstawia nowy obraz tomisty, który może powodować dysonans w środowisku kościelnym: „laika, a nie duchownego,

\footnotetext{
20 Por. tenże, Le crépuscule de la civilisation, dz. cyt., s. 14.

21 Por. tenże, Antimoderne, dz. cyt., s. 1013.

22 Por. tamże, s. 1018.

23 Tenże, Carnet de Notes, Desclée de Brouwer, Paris 1965, s. 92.
} 
filozofa, a nie egzegety"24. To daje mu jednocześnie większą swobodę w interpretacji nauczania św. Tomasza. Ponadto historia jego życia ma głęboki wpływ na jego pozycję jako autorytetu naukowego. Stary i gorliwy uczeń Bergsona, nawrócony, laik, Jacques Maritain zmienia swoją linię badań i przedstawia tomizm jako myśl zdolną do konfrontacji ze współczesnym światem. Wszystkie te wydarzenia są istotne i pomagają zrozumieć reputację Maritaina. $Z$ metodologicznego punktu widzenia tomizm zapewnia w badaniach filozoficznych „tendencję uniwersalistyczną"25, która poszukuje wszędzie elementów wspólnych zamiast podziałów, zalążków prawdy zamiast dewiacji.

Po raz pierwszy Maritain prezentuje myśl św. Tomasza z Akwinu w roku 1913, jako wykładowca Instytutu Katolickiego w Paryżu. Jego aklamacja: „,biada mi, gdybym nie tomizował"26 pokazuje nam jego kierunek poszukiwań. Konferencje dotyczące filozofii Bergsona i jej niewystarczalności (La Philosophie de M. Bergson et la philosophie chrétienne) są jedną z pierwszych prezentacji odrodzonego tomizmu, gdzie Maritain analizuje ścisłą jedność między rozumem a wiarą. Oba wymiary zapewniają odkrycie całego bogactwa inteligencji w jej wymiarze naturalnym, ale także nadprzyrodzonym ${ }^{27}$. Owe konferencje są krytyczną analizą filozofii Bergsona, ale jednocześnie stanowią pierwszy wykład myśli tomistycznej u Maritaina. Można powiedzieć, że to pierwsza publikacja, która podkreśla cel całego dorobku Maritaina: poszukiwania prawdy o człowieku i zrozumienie rzeczywistości w jej najgłębszych wymiarach.

Studia nad tomizmem nie były dla Maritaina tylko powtórzeniem scholastycznych idei. Nie jest to kwestia powrotu do średniowiecza, ale dialogu z rzeczywistością poprzez rozwiązania, jakie proponuje tomizm. W ten sposób Maritain przedstawia całkowicie inną wizję świata, w której akcentuje się wymiar duchowy i konieczność wiecznych norm ${ }^{28}$. Św. Tomasz był przewodnikiem, który ujawnia prawdę o człowieku. Odkrywając to, Maritain chce nawiązać dialog ze współczesnym światem. Maritain nawet precyzuje, że konieczne jest naśladowanie św. Tomasza w jego „,nowoczesności” i ,śmiałości do innowacji, w swojej intelektualnej odwadze" ${ }^{29}$. Innymi słowy, filozof stara się znaleźć odpowiedzi na aktualne problemy, odwołując się do rozwiązań zaproponowanych przez Akwinatę. Oznacza to, że filozof, w przeciwieństwie do Gilsona, zachowuje swą swobodę myślenia w odniesieniu do św. Tomasza. Niemniej jednak jest on zainspirowany

${ }^{24}$ C. Langlois, La naissance de l'intellectuel catholique, w: Intellectuels chrétiens et esprit des années 1920, red. P. Colin, Les Éditions du Cerf, Paris 1997, s. 231.

25 J. Maritain, Le Docteur Angélique, dz. cyt., s. 19.

26 Jacques Maritain w taki sposób wyraża związek z tomizmem: «malheur à moi si je ne thomistise pas». Por. tenże, Confession de foi, Euvres Complètes, 1991, t. XI, s. 28.

27 Por. tenże, La Philosophie bergsonienne, dz. cyt., s. 291.

28 Por. tenże, Antimoderne, dz. cyt., s. 934.

29 Tenże, Le Docteur Angélique, dz. cyt., s. 113. 
geniuszem św. Tomasza i kontynuuje rozpowszechnianie idei scholastycznych. Maritain uważa tomizm za tradycję, która wciąż żyje i ma zastosowanie w konfrontacji z problemami czasu. Filozof mówi o sobie, że jest spadkobiercą św. Tomasza, obok Kajetana lub Jana od świętego Tomasza. W ten sposób przedłuża jego myśl, wykorzystuje ją, aby konstruować własny pogląd na świat ${ }^{30}$. Zatem, Maritain pojmuje tomizm jako doktrynę, której trwałość jest jej własnym charakterem, a która dziś jest tak samo aktualna, jak wczoraj.

\section{a. Prawda w swych wymiarach najbardziej rygorystycznych}

Encyklika papieża Leona XIII otworzyła nową erę badań nad tomizmem, szczególnie w środowisku uniwersyteckim w Europie. W tym czasie powstają najważniejsze ośrodki badawcze, które rozpowszechniają myśl Akwinaty: Wyższy Instytut Filozoficzny w Louvain (1889), Wydział Teologii Katolickiej we Fryburgu w Szwajcarii (1890), Wydział Filozoficzny Instytutu Katolickiego w Paryżu (1895). Jednym z powodów odnowienia tomizmu było przeciwstawienie się tendencjom, gdzie wymiary wiary i intelektu pozostają $\mathrm{w}$ opozycji jedna do drugiej. W odpowiedzi Kościół jednocześnie odrzuca dewaluacje rozumu, a także jego waloryzację ze szkodą dla wiary. Uwaga ta jest istotna w koncepcji świata u Maritaina, ponieważ komplementarność między tymi dwoma wymiarami pozwoliła mu nie tylko odkryć inteligencję tomizmu, ale przede wszystkim dążyć do prawdy w jej zewnętrznym i wewnętrznym wymiarze. Wiara i rozum to dwa dobra wyjaśniające prawdę, którą Maritain zgłębiał przez całe życie. Ponadto samą kontemplację Maritain określa jako sposób, poprzez który prawda ukazuje się w całym swoim bogactwie. Filozof prezentuje swoją myśl w ten sposób: „uważam, że filozofia jest dziełem rozumu i opiera się na naturalnych dowodach, a nie na wierze - ale sam rozum nie jest zamkniętym światem, ale otwartym. Spełnia on swoje zadanie i osiąga swoją własną pełnię tylko wtedy, gdy jest wspomagany i ożywiony przez światła, które pochodzą z wiary"31.

Zatem, ujęcie rzeczywistości, tak jak to proponuje Akwinata, stanowi dla Maritaina najbardziej rygorystyczną odpowiedź w poszukiwaniu prawdy. Św. Tomasz z Akwinu pozostawia prawdzie całą swoją wielkość. Całe jej bogactwo jest w bycie. Nie ma nic oprócz prawd inteligibilnych, potrzeb i wymagań najwyższych zasad, które decydują o jej rozwiązaniach. Ta prawda ma charakter trwały, nawet wieczny, ponieważ nie uznaje kryterium chronologicznego ${ }^{32}$. Tak więc prawda, tak jak prezentuje ją św. Tomasz z Akwinu, jest dla Maritaina wciąż

30 Por. tenże, Antimoderne, dz. cyt., s. 931.

31 Tenże, De Bergson à Thomas d'Aquin. Essais de Métaphysique et de Morale, Éditions de la Maison Française, New York 1944, s. 135.

32 Por. tenże, Sept leçons sur l'être et les premiers principes de la raison spéculative, Téqui, Paris 1934, s. 8. 
aktualna w kontekście współczesności. W tomizmie widzi doktrynę, która przedstawia rozwiązanie problemów, z którymi trzeba się zmierzyć, opierając się na niezastąpionej roli intelektu w dialogu z modernizmem. Tomizm w swym wymiarze intelektualnym pozwala zrozumieć prawdziwe znaczenie wszystkich prawd. W konsekwencji prowadzi zawsze do intelektualnego odrodzenia ${ }^{33}$. W tej perspektywie Maritain używa sformułowanie «reparacja intelektualna» (la réparation intellectuelle), aby podkreślić także niezmienne miejsce Boga jako najwyższego przedmiotu inteligencji; prawdy zaniedbanej przez ówczesnych intelektualistów. Wreszcie siła intelektualna tomistycznej doktryny pozwoliła mu stawić czoło przed opinią, jakoby teologia nie miała miejsca w dyskusji naukowej, a doktryna przedstawiona przez Kościół nie ma żadnej wartości metodycznej.

W rezultacie, system Akwinaty zachęca Maritaina do badań nad człowiekiem w jego wymiarze zarówno indywidualnym, jak i społecznym, opierając się na danych rozumu. Maritain stwierdza, że doktryna Akwinaty czerpie całą swą siłę $\mathrm{z}$ tego, co jest najbardziej naturalne $\mathrm{w}$ człowieku ${ }^{34}$. W ten sposób próbuje odpowiedzieć na modernistyczne idee, które doprowadziły do całkowitej dewaluacji osoby ludzkiej. Jean-Luc Barré podkreśla, że wielką wartością Maritaina w badaniach jest osobiste przyswojenie tomizmu, ponieważ znajduje w nim nie tylko odpowiedni warsztat doktrynalny zgodny z jego własnymi intuicjami, ale także źródło egzystencjalnej nadziei, dającej siły do życia. Osobliwość Maritaina w odniesieniu do tomizmu polega zatem nie tylko na pracy intelektualnej, ale również na osobistym wykorzystywaniu jego zasad ${ }^{35}$. W tym sensie, studiowanie tomizmu jest dla niego formą apostolatu.

\section{b. Św. Tomasz jako apostoł czasów współczesnych}

Doktryna św. Tomasza z Akwinu charakteryzuje się tym, że w sposób najbardziej dogłębny i adekwatny do możliwości intelektualnych chce ująć rzeczywistość, aby ujawnić głęboką prawdę o człowieku. Mianowicie jest on w stanie stawić czoło problemom, które spostrzegamy, pod warunkiem, że intelekt zrobi konkretny wysiłek, aby zrozumieć pewne procesy i mechanizmy. W ten oto sposób św. Tomasz z Akwinu jest ,,apostołem inteligencji, doktorem prawdy, restauratorem ładu intelektualnego, św. Tomasz nie pisał dla XIII wieku, pisał dla naszych czasów"36. Dzieje się tak dlatego, że Akwinata pozwala odkryć na nowo siłę i moc inteligencji, dlatego można go nazwać apostołem czasów współczesnych.

Doświadczenie metafizyczne jest najdokładniejszym sposobem zrozumienia owej rzeczywistości. Chodzi o to, by nie tworzyć prawd, które usprawiedliwiają

33 Por. tenże, Carnet de Notes, dz. cyt., s. 398.

34 Por. tenże, La Philosophie bergsonienne, dz. cyt., s. 27.

35 Por. J.-L. Barré, Jacques et Raïssa Maritain. Les mendiants du ciel, Perrin, Paris 2012, s. 138.

36 J. Maritain, Le Docteur Angélique, dz. cyt., s. 110. 
ludzkie działanie, ale przeciwnie, aby odkryć prawdy, którym człowiek będzie służyć. Nie można się zadowalać każdą prawdą, lecz trzeba szukać uniwersalnych prawd. Umożliwiają one postrzeganie człowieka w określonych okolicznościach i zawsze podkreślają jego egzystencjalne warunki. Inteligencja dąży wówczas do zrozumienia prawdy w jej pierwotnym kształcie, zachowując nierozerwalny związek z logiką i rzeczywistością. Maritain definiuje tę postawę Akwinaty jako absolutyzm prawdy ${ }^{37}$. Dla filozofa francuskiego badania muszą więc być pozbawione stronniczości, wszelkiej ideologii i otwarte tylko na „pierwszą prawdę, z której wszystkie rzeczy procedują w bycie" ${ }^{\prime 3}$. W tej perspektywie metafizyka jest podstawą nie tylko wszystkich systemów filozoficznych, ale także rozumienia świata, co pozwala przezwyciężyć myśl o przypadkowości ludzkiej egzystencji.

Poszukiwanie prawdy u Maritaina zakłada intelektualny wysiłek, aby odczytać rzeczywistość i ją ująć, zarówno po stronie istoty, jak i po stronie istnienia. Jest to wymiar egzystencjalny, który pozwala nam uchwycić świat i człowieka w ich prawdziwym obrazie. Wielką zasługą Maritaina, ale także samego Gilsona, jest właśnie włączenie tomaszowej teorii istnienia w metafizykę. Jej odkrycie wymaga intelektualnego podejścia, ponieważ intelekt ma zasadniczo obiektywny charakter. Dla Maritaina inteligencja znajduje prawdziwą radość tylko w relacji z bytem. Kiedy mówi « inteligencja » - ma na myśli inteligencję chrześcijańską, udoskonaloną przez nadprzyrodzone dary. Ona to kształtuje rozumowanie, podążając za samą linią nauki i wychodząc poza naukę ${ }^{39}$. W konsekwencji, przez zjawiska empiryczne i przez filozofię przyrody dochodzimy do metafizyki, aby potem dołączyć do teologii i budować rzeczywistość na innym poziomie, zależnym od miłości i darów Ducha Świętego ${ }^{40}$. Doktryna św. Tomasza powoduje zatem, że Maritain opiera swoje tezy nie tylko na inteligencji, lecz także odwołuje się do rzeczywistości nadprzyrodzonej, co nie jest ani sprzeczne, ani nie do pogodzenia. Filozof zapewnia nas w ten sposób: „tomistyczna myśl dąży do jedności w człowieku, a tym samym do przygotowania go do pokoju, który przewyższa wszelkie uczucia, poprzez pogodzenie w nim łaski i natury, wiary i rozumu, teologii i filozofii, porządku duchowego i porządku czasowego"41. Jest więc oczywiste, że koncepcja człowieka w myśli Maritaina zawsze opiera się na teocentrycznym podejściu, które stanie się podstawowym punktem humanizmu integralnego.

Doktryna św. Tomasza z Akwinu akcentuje zatem prymat inteligencji w odniesieniu do woli w porządku spekulatywnym, ale także w praktycznym wymiarze. W ten sposób św. Tomasz z Akwinu ,przywraca inteligencji jej własny przedmiot,

37 Por. tamże, s. 105.

38 Tamże, s. 108.

39 Por. tenże, Antimoderne, dz. cyt., s. 1044.

40 Por. tamże, s. 1044.

41 Tenże, De Bergson à Thomas d'Aquin, dz. cyt., s. 133. 
orientuje ją do właściwego celu i przywraca jej naturalny charakter"42. Jest otwarta na byt i dlatego prosi człowieka, aby nią się posługiwać w celu odkrycia rzeczywistości. Jej uprzywilejowanym zadaniem jest to, że „musi działać dla wspólnego dobra wszechświata i ludzkości" ${ }^{43}$. Jest zatem niezbędnym, aby odkryć właściwe życie intelektu, aby zobaczyć w rozumie „obiektywność wiedzy i wartość nauki o bycie" ${ }^{44}$. To jest powód, dla którego Maritain będzie nieustannie powtarzać pilny obowiązek apostolatu, który pozwala nam współpracować z innymi systemami, pomimo różnicy przekonań: apostolatu inteligencji. Odkrywając naturę inteligencji i właściwe jej życie, człowiek zmierza ku uniwersalnej prawdzie, bez niebezpieczeństwa fałszywych rozwiązań. Dlatego zanim powstaje twierdzenie lub sąd, trzeba zdefiniować sposób, poprzez który człowiek poznaje. Zatem, proponowana przez św. Tomasza teoria wiedzy pozwala nam zachować obiektywny charakter badań w odniesieniu do „fałszywej metafizyki, która nam zagraża”45. Działanie inteligencji jest przede wszystkim immanentne. Oznacza to, że jej wrodzona zdolność poznawcza jest naturalna, a jej zadaniem jest doskonalić wszystkie rzeczy. W procesie poznawania, określona rzecz uczestniczy w życiu inteligencji, a następnie sama inteligencja przyswaja tę rzecz niematerialnie. Zatem istotną cechą inteligencji jest jej zależność od przedmiotu. W związku z tym, gdy Maritain mówi o wolności inteligencji, podkreśla fakt bycia kierowanym przez przedmiot i przestrzegania wymagań przedmiotu. Jest ona wtedy wolna do tego stopnia, że dostrzega coś, co jej się objawiło. Wynika z tego, że obiektywna wartość intelektu jest fundamentalna, ponieważ pozwala nam uniknąć pewnych nieporozumień, takich jak wizja inteligencji jako celu człowieka lub jej podporządkowanie praktycznemu działaniu.

Tomizm służy więc Jacques'owi Maritainowi do wypracowania konkretnej teorii poznania i w konsekwencji do konstruowania pojęć, w szczególności pojęcia bycia jako bytu. Analizując system Maritaina, polski filozof Edmund Morawiec zauważa, że na początku istnieją poznawalne fakty, które wyrażają się w sądzie egzystencjalnym. Są to fakty, które dostrzegamy i które zawierają prawdę egzystencjalną. Są one dane nam w doświadczeniu ludzkiej wiedzy. Fakt należy do porządku rzeczy ${ }^{46}$. Takie rozumowanie daje mu spojrzenie na tomizm jak na doktrynę, która chce poznać rzeczywistość w jej najgłębszych wymiarach. W ten sposób Maritain przeciwstawia się nie tylko idealistycznym wizjom wiedzy filozoficznej, ale także odkrywa ogromne zagrożenie dla prawdy: zniekształcenia faktów, które nie odpowiadają rzeczywistości. Właśnie to zjawisko określamy

42 Tenże, Le Docteur Angélique, dz. cyt., s. 109.

43 Tenże, Théonas, Euvres Complètes, 1987, t. 2, s. 775.

44 Tenże, Le Docteur Angélique, dz. cyt., s. 69.

45 Tamże, s. 69.

46 E. Morawiec, Intellectual Intuition in the General Metaphysics of Jacques Maritain, Edition Peter Lang, Frankfurt am Main 2013, s. 41-43. 
mianem ery post-prawdy. Paul Valadier widzi w tym niebezpieczeństwo, które niszczy całkowicie życie wspólnotowe: „odmowa prawdy - mówi nam autor odpowiada odmowie powiedzenia rzeczy takimi, jakie są lub próbie handlu z rzeczywistością" ${ }^{47}$. Wówczas dana informacja jest pozbawiona wszelkiego prawdopodobieństwa. $Z$ tej perspektywy wyraźnie widać ogromną wartość rozumowania zgodnego z rzeczywistymi faktami. W ten sposób Maritain przedstawia nam nie tylko konieczność takiego budowania wizji świata, między innymi dlatego, że pozwala on budować prawdziwe relacje międzyludzkie.

\section{c. akt istnienia}

Jacques Maritain znalazł u św. Tomasza z Akwinu kolejny klucz, wyjaśniający wizję człowieka: akt istnienia, rozumiany jako wymiar konieczny w procesie analizy rzeczywistości. Innymi słowy, dzięki studiom Sumy Teologicznej, filozof odkrywa metafizykę w swoim egzystencjalnym aspekcie i otwiera nową perspektywę w swoich refleksjach antropologicznych, gdzie akt istnienia umożliwia analizę rzeczywistości, badając zarówno to, co jest, jak i fakt konkretny tego, co jest. Dlatego pojęcie „byt” oznacza dla Maritaina przedmiot samego intelektu. Ponadto, według niego istnienie nie może być pomijane, ponieważ tworzy jedność $\mathrm{z}$ istotą. W tej perspektywie istnienie nie jest przypadkowe, ale jest częścią całości. Innymi słowy, rzecz jest prawdziwa wtedy, kiedy istnieje. Jest ona zdeterminowana istnieniem i dzięki temu człowiek jest w stanie zrozumieć rzeczywistość samą w sobie. Egzystencja pozwala odkryć inteligibilność rzeczywistości.

Dla Maritaina egzystencjalizm nie jest czystym dyskursem, ale podstawą humanizmu, ponieważ spojrzenie na człowieka $\mathrm{w}$ akcie jego istnienia pozwala nam dostrzec niezmienną bazę ludzkiego życia i demonstruje specyfikę człowieka w konkretnych działaniach. Istnienie zatem może być przedmiotem badania intelektualnego, a także stanowić pomoc w określaniu wartości, którymi człowiek się kieruje. Właśnie dlatego klasyfikujemy tomizm Jacques’a Maritaina jako egzystencjalny, co pozwala nam spojrzeć na człowieka nie tylko w wymiarze ilościowym, ale także jakościowym, ponieważ istnienie jest aktem, który trwa sam w sobie, subsystuje ${ }^{48}$. Anna Lendzion, a także ks. profesor Wojciech Cichosz podkreślają wymiar praktyczny egzystencji człowieka, który ma swoje konkretne zastosowanie w pedagogice. Egzystencjalny model bytu rysuje nie tylko jego istotną strukturę, ale także jego działania, obserwowalne w doświadczeniu. I właśnie ten aspekt wydaje się nam fundamentalny w naszych rozważaniach nad uniwersalizmem tomizmu u Maritaina. Egzystencja aktualizuje złożoną istotę

47 P. Valadier, Péril en démocratie: la post-vérité, „Études, Revue de culture contemporaine”, (2017)5, s. 55-63.

48 Por. J. Maritain, De Bergson à Thomas d'Aquin, dz. cyt., s. 132. 
w konkretnym bycie, a więc wskazuje również konkretne działania człowieka ${ }^{49}$. Doktryna Akwinaty jest zatem silnie spójna, ale i nieskończenie postępowa, lecz zawsze wierna temu co jest. W ten sposób samo działanie człowieka, jak i jego moralne postępowanie pozostaje w ścisłym związku z uniwersalnymi zasadami.

Zatem, doktryna św. Tomasza z Akwinu jest niezbędna, aby zrozumieć wizję człowieka u Maritaina, ponieważ umożliwia ona otwarcie intelektu na poznanie tego, co jest trwałe i uniwersalne. W konsekwencji, koncepcja człowieka przedstawiona przez Akwinatę nie jest ani heterogeniczna, ani absolutnie autonomiczna. Wykracza poza jednostronny dyskurs i subiektywne wypowiedzi. Innymi słowy, według Maritaina, tomistyczna doktryna jest tak skomponowana, aby być obiektywnie i przede wszystkim intelektualnie weryfikowalną. Maritain traktuje system Akwinaty jako fundamentalny punkt odniesienia, ponieważ jest nie tylko uporządkowany metodologicznie, ale odnosi się do obiektywnie istniejącej rzeczywistości. Postulaty Anielskiego Doktora nie są abstrakcyjne. Wręcz przeciwnie, są one uzasadnione racjonalnie. W tej perspektywie metafizyka Akwinaty jest dla Maritaina sposobem odczytania rzeczywistości, w której jest miejsce dla każdego stworzenia, a także dla Boga. Tak więc, zainspirowany przez św. Tomasza z Akwinu, Maritain pozostaje wierny rzeczywistości i zwraca się do niej przede wszystkim po stronie jej istnienia. Dlatego często mówimy o wymiarze egzystencjalnym metafizyki Akwinaty w filozofii Maritaina.

\section{PODSUMOWANIE}

Maritain pragnie rozwiązać problemy swojej epoki w świetle tomistycznej doktryny, aby znaleźć nie tyle odpowiedź, ile prawdę wyjaśniającą problem. Dla Maritaina, św. Tomasz z Akwinu jest nie tylko teologiem, ale także metafizykiem inteligencji i rozumu, poprzez które pragnie udowodnić i obronić autentyczną zdolność poznania rzeczywistości. W tej linii, analizując Akwinatę, Maritain próbuje uratować wszystko to, co jest nadal wartościowe we współczesnym świecie, i ponownie to wykorzystać, aby udowodnić, że porządek mądrości istnieje ${ }^{50}$. To właśnie dogłębna analiza wymiaru uniwersalnego tomizmu stanowi o oryginalności myśli Jacques'a Maritaina.

System św. Tomasza z Akwinu staje się dla Maritaina punktem oparcia w jego wizji człowieka, ale stanowi także skarbnicę argumentów w dialogu z modernizmem. W tym sensie św. Tomasz ,wydaje się nam wielkim intelektualnym rekon-

49 Por. A. Lendzion, Koncepcja podmiotu osobowego w personalizmie Jacques'a Maritaina, „Roczniki Pedagogiczne”, 2(2010)38, s. 5-20; W. Cichosz, Implikacje pedagogiczne antropologii Maritaina, „Studia Gdańskie”, 13(2000), s. 159-173.

50 Por. J. Maritain, Le Docteur Angélique, dz. cyt., s. 115. 
struktorem Zachodu"51. Tomizm jest zatem aktualny nie tylko dla wierzących, ale dla każdego, kto uważa za konieczne obronę człowieka poprzez nową wizję antropologii. Bez wątpienia św. Tomasz z Akwinu zapewnia im znaczną pomoc, przede wszystkim dzięki myśleniu opartemu na inteligencji. Sam Maritain mówi, że tomizm jest w stanie pomóc inteligencji, a nawet zachować ją od deformacji. W tym sensie moglibyśmy powiedzieć, bez niebezpieczeństwa błędu, że dla Maritaina geniusz Akwinaty polega na tym, że komunikuje się z przyszłością. Owa głębia myśli średniowiecznej jest wyzwaniem dla nowego pokolenia, aby ją nieustannie aktualizować. W tej perspektywie francuski filozof powie, że jeśli tomizm musi być pielęgnowany, to dlatego, że jest ogromnym dobrem i pokazuje, jak należy żyćs ${ }^{52}$. Doktryna św. Tomasza pozwala znaleźć odpowiedzi na trudności egzystencjalne obecne w każdej epoce, dlatego o jego tezach mówimy, że są uniwersalne.

\section{Bibliografia}

Barré J.-L., Jacques et Raïssa Maritain. Les mendiants du ciel, Perrin, Paris 2012.

Cichosz W., Implikacje pedagogiczne antropologii Maritaina, „Studia Gdańskie", 13(2000), s. 159-173.

Cocteau J., Maritain J., Correspondance 1923-1963, red. M. Bressolette, P. Glaudes, Éditions Gallimard, Paris 1993.

Fumet S., Amour de la sagesse et amitié des hommes, „Recherches et débats du centre catholique des intellectuelles français", (1957)19, s. 23-33.

Gilson É., Maritain J., Correspondance 1923-1971, Librairie Philosophique J. Vrin, Paris.

Kowalczyk S., Jacques Maritain (1882-1973), Tomista otwarty na wspótczesność, w: Jacques Maritain prekursor soborowego humanizmu, red. E. Balawajder, S. Kowalczyk, Wyd. KUL, Lublin, 1992, s. 9-24.

Krol B., Osobowość, wolność i rozumność człowieka w świetle wybranych dziet Jacques'a Maritaina, „Studia Teologiczno-Historyczne Śląska Opolskiego”, (2014)34, s. 53-66.

Langlois C., La naissance de l'intellectuel catholique, w: Intellectuels chrétiens et esprit des années 1920, red. P. Colin, Les Éditions du Cerf, Paris 1997.

Lendzion A., Koncepcja podmiotu osobowego w personalizmie Jacques'a Maritaina, „Roczniki Pedagogiczne”, 2(2010)38, s. 5-20.

Maritain J., Antimoderne, Euvres Complètes, 1987, t. II.

51 Tamże, s. 77.

52 Por. É. Gilson, J. Maritain, Correspondance 1923-1971, Librairie Philosophique J. Vrin, Paris, s. 262. 
Maritain J., Carnet de Notes, Desclée de Brouwer, Paris 1965.

Maritain J., Confession de foi, Cuvres Complètes, 1991, t. 11.

Maritain J., Court traité de l'existence et de l'existent, Euvres Complètes, 1990, t. 9.

Maritain J., De Bergson à Thomas d'Aquin. Essais de Métaphysique et de Morale, Éditions de la Maison Française, New York 1944.

Maritain J., La Philosophie bergsonienne, Euvres Complètes, 1986, t. 1.

Maritain J., Le crépuscule de la civilisation, Euvres Complètes, 1988, t. 7.

Maritain J., Le Docteur Angélique, CEuvres Complètes, 1983, t. 4.

Maritain J., Le Paysan de la Garonne, Desclée De Brouwer, Paris 1966.

Maritain J., Lettre sur l'indépendance, Desclée de Brouwer, Paris 1935.

Maritain J., Sept leçons sur l'être et les premiers principes de la raison spéculative, Téqui, Paris 1934.

Maritain J., Théonas, Euvres Complètes, 1987, t. 2.

Maritain J., Trois réformateurs, Euvres Complètes, 1984, t. 3.

Morawiec E., Intellectual Intuition in the General Metaphysics of Jacques Maritain, Edition Peter Lang, Frankfurt am Main 2013.

Valadier P., Péril en démocratie: la post-vérité, „Études, Revue de culture contemporaine", (2017)5, s. 55-63.

\section{Streszczenie}

W niniejszym artykule autor studiuje poglądy filozoficzne Jacques'a Maritaina, aby następnie przeanalizować jego ścisły związek z doktryną św. Tomasza z Akwinu, ujmując ją jako uniwersalną. W pierwszej części swojej pracy autor analizuje kontekst czasu i wynikające z niego procesy, takie jak: degradacja inteligencji, marginalizacja metafizyki i zanegowanie wymiaru nadprzyrodzonego. Te elementy zostały w sposób szczególny omówione przez autora. Doktryna św. Tomasza otwiera mu zatem nową perspektywę badań. W sposób szczególny pozwala ona dostrzec siłę intelektu i bogactwo rzeczywistości, rozpatrywanej nie tylko od strony istoty, ale i istnienia. Te aspekty tomizmu powodują, że Maritain określił doktrynę Akwinaty jako uniwersalną i wciąż aktualną, jako naukę, która ma zastosowanie w każdej epoce.

Słowa kluczowe : intelekt, istota, Maritain, modernizm, personalizm, prawda, rzeczywistość, tomizm, św. Tomasz z Akwinu, uniwersalizm 
The Universal Character of Thomism

and its Contemporary Relevance according to Jacques Maritain's Personalism

\begin{abstract}
Summary
In this article we analyse the philosophical views of Jacques Maritain and his close ties to the doctrine of Saint Thomas Aquinas which he sees as universal. The first part is devoted to the process of the decline of metaphysics and the negation of the supernatural. However, the ideas of the Angelic Doctor open a new perspective for the research on the power of the human intellect and the complexity of reality considered not only from the aspect of being but also from that of existence. Aquinas' system becomes the basis for Maritain's vision of man, allowing him to enter into the dialogue with modernism. He defined the doctrine of Saint Thomas as universal and valid as a science that is applicable in every age and its most important aspect is its realism. In his writings Maritain discovers Thomism as a thought that allows us to fully understand the world and the mankind. Aquinas' teaching does not lose anything of its relevance, also in the field of the moral values, yet it must be constantly developed. In this sense, it is a challenge for every generation of thinkers.
\end{abstract}

Keywords: rationality, substance, Maritain, modernism, personalism, truth, reality, Thomism, St Thomas Aquinas, universalism 